\title{
資本利用型農業経営と農協の与信制御の動学分析 農業経営の安定性に関連して
}

神門善 久

\section{1.はじめに}

近年，資本利用型農業経営（畜産，とくに養豚）に おける固定化負債問題が深刻化しており, これに関連 していくつかの研究が抢てなわれてきだ，資本利用 型農業経営の特徵として, 枝肉価格や生産技術などの 経営環境の変動が激しいとと, 資金需要が多額でその 大部分を農協信用事業に依存していること，をあげる ことができる. 本稿の課題は, 農業経営が環境の変動 に直面している場合について, 農協与信が農業経営に 与える影響を，理論的に明らかにするてとである.

本稿では経済動学の概念をふまえ, 農業経営が一定 速度で規模扗大する状態を均衡状態ととらえる. 均衡 状態における規模桩大の速度は経営環境に適合したも のでなければならない，経営環境はつね変動するも のであり，その変動に応じて規模㧪大の速度も調整さ れなければならない，たとえば枝肉価格の下落時に無 理な規模拡大を抏てなって経営破たんに陷る場合があ るが，乙れは経営環境の変動に農業経営がうまく適合 できなかった場合であると判断できる.

均衡状態が変化するとき, 新しい均衡状態へ移行で きるか否かの検討, ならびにその速度の検討, は経済 動学における安定性分析といわれる2). 新しい均衡状 態への移行が可能か否かを判別するのが動学的安定条 件であり，新しい均衡点への移行が可能であること （動学的安定条件が満たされること）を「安定」, 逆 の場合を「不安定」之表現する. 不安定であったもの が安定へと变わること, あるいは均衡へ移行する速度 が速まることを「安定性が高まる」と表現し, 逆を「安 定性が低まる」と表現する. 以上のような安定性の概 念を農業経営に適用し, 農業経営の安定性を 分析す る. また, 農協が農業経営の状態を観察, 評価し, そ の結果にしたがって農業経営に対する農協与信（購買 未収金などあふくめた広義の与信)を調整するととを， 「農協の与信制御」と表現する. 農協が適切な与信を おこなって農業経営の安定性を高めることを,「農協
の与信制御による農業経営の安定性強化」と表現す る.

資本利用型農業経営の安定性を高めることが, 近年, 農政の重要問題亡なっており，そのために農協与信に 期待されるところはきわめて大きい3)。従来の研究は 事例調查を中心としたものが多く,一方, 本稿のよう に農業経営の安定性と農協与信の関係を理論的に整理 するこころみは，いまだに不十分な段階にあると思わ れる. 従来の研究に比して本稿の理論分析は, 次の 2 点において特徽がある. 第 1 は, 動学的枠組みを明示 している点である. この枠組みによって農業経営の行 動パターンを明示的に表現できる. 第 2 亿, 農業経営 の経営環境の変動を,「平均値の变動っと「確率的翼乱」 に分けて議論している点である. 前者は均衡値の水準 を変える一度かぎりの変動であり, 石油危機などの構 造的変動である. 後者は, 平均的には一定值をとりつ つ繰り返しランダムに発生する変動であり, 枝肉佂格 の短期的な上昇・下降運動がその一例である. 後にみ るように両者は安定性分析上異なった性格を持ってお り，両者を区分して論じるてとは有用であると考え る.

以下，第 2 節では農業経営と農協与信を理論モデル 化し, 農業経営の安定性を数式で表現する. 第 3 節で はそれにもとづいて経済学的考察をおてなう．制度金 融（近代化資金制度など），預託，購買未収金，組合 員勘定といった与信形態をとりあげ，それらの性格を 農業経営の安定性之関連づけて明らかにする．第 4 節 では，ま之め上今後の課題を述べる。

\section{2. 農協与信・農業経営の動学モデルと安定 性分析}

枝肉価格，生産技術などの経営環境の变動があるも とでの農業経営, 農業与信の行動を動学モデルで表現 し，安定性分析をおこなう．モデルの構築ならびに分 析手法については, 吉田 ${ }^{4)}$, 吉川(5), ターノフスキー6), 木村7を参考としている。 
モデルの構築を容易にするために，肥育猄業養豚を 念頭におき，いくつかの単純化の仮定をおく．畜含， 肥育期間の問題は考慮せず，仔豚を導入して成豚之し て出荷することによって収益をあげるものとする．農 業経営の自己資本は一定であると仮定する．資本の限 界生産性は一定で平均生産性之一致すると仮定する。 投資行動之枝肉価格についてのみ確率的確乱を考慮 し, 仔豚価格, 飼料価格はとりあえず一定と仮定する. てれらの仮定を緩めたり，肥育専業養豚以外の資本利 用型豊業に適用すべくモデルを修正することは可能で あるが，その場合でも，農協与信之農業経営の安定性 との関係に関する本稿の分析結果は，基本的に維持さ れる。

\section{(I) 分析モデルと仮定}

まず本稿のモデルで使用する文字を一括してしるし ておく.

$E:$ 農業経営の期待投、資額 ${ }^{8)}$

$K:$ 農業経営の現笑の投資額 8

$M:$ 農協の新規与信額

$W$ : 農業経営の家計資産（お屯に預眝金）残高

$Z_{\kappa}, Z_{p}$ ： 標準化された Wiener 過程にしたがう変 数 $(d Z \sim N(O, \sqrt{d t}))$

$f:$ 農協の新規与信関数（制御関数）

$g$ : 資本の物的生産性（資本生産性を枝肉量ではか ったもの)

$i$ : 資本 (総資本) 調達利子率

$p:$ 生産物（枝肉）価格（確率変数）

$q:$ 生産物価格の平均值加らの乘離部分

$r:$ 期待資本収益率

$t:$ 時間を表わす変数

$\alpha, \beta$ : 調整係数 $(0<\alpha, \beta<1)$

$\delta:$ 生産物価格の上昇吕資本収益率の期待形成に与 える効果を表わす俰数 $(>0)$

$\sigma_{\mathfrak{p}}, \sigma_{\boldsymbol{\kappa}}$ : (瞬時的) 標準偏差

*：均衡値を表わすノーテーション

一：平均値を表わすノーテーション

ここでKは資本(ストック)を表現するのではなく， 各時点における投資額，すなわち規模桩大の速度を表 わすフロー変数である点汇注意して欲しい．経営環境 の変動に直面しつつ規模拡大による所得上昇をめざす という資本利用型農業経営の特質をモデル化するた め, このようなフロー变数に注目した，同様にMむフ ロー変数であって与信残高ではない，また，吉川 ${ }^{5)}$, ターノフスキー6) とならって，経済現象における不確
実性をWiener 過程とよばれる確率過程を用いて表現 した. Wiener 過程にしたがう確率変数は，その增分 が正規分布にしたがって連続的に变化するという特徵 を持つ9).

〈諸仮定 $(A 1 \sim A 6)>$

(A 1) 農業経営は期待資本収益率之資本調達利子率 にもとづき，期待投資額を決める.

$$
E=E(r, i)
$$

通常，期待投資額 $\mathrm{E}$ は期待資本収益率 $\mathrm{r}$ の增加関数 $\left(E_{r} \equiv \partial E / \partial r>0\right)$, 資本調達利子率 $\mathrm{i}$ の減少関数 $\left(E_{i} \equiv\right.$ $\partial E / \partial i<0)$ である.しかし，農業経営がしばしば所得 水準の低下を過度に忌避する傾向があり，収益率の悪 化に 対し 規模桩大で対応する場合も少なからずある (たとえば註 1 の平川文献参照)。乙の場合は，期待 投資額は期待収益率の減少関数となる $\left(E_{r}<0\right)$.

（A 2 ） 農業経営の現実の投資額 Kは次式で決まる.

$$
d K=\alpha(E-K) d t+\sigma_{\kappa} K d Z_{\kappa}
$$

農業経営がしばしば計画性のそしい投資をおこなう 之いわれる(例えば，註 1 の頼・糸原・横溝参照)が， （A 2 $)$ はこれを考虑した仮定である. 即ち, 農業経営 は現場の投資額を期待投資額的調整する(右辺第 1 項) のみならず，経営計画との整合性を欠いた，たぶん気 まぐれ的な投資誘因が存在する（右辺第 2 項）のであ る. 記帳すら十分におてなっていない農業経営がしば しば見られるが，その場合，期待資本収益率や自己資 本利子率に対する農業経営の意識は弱く，いきおい気 まぐれ的な投資行動をとりがちである．右辺第 2 項は このことを表現しており， $\sigma_{\kappa}$ が大きいほど，計画性の 乏しい投資誘因が大きいてとを表わしている.

（A 3 ） 生産物価格は次式にしたがう

$$
\begin{aligned}
& p=\bar{p}+q \\
& \text { ただし } d p=d q=\sigma_{p} d Z_{p}
\end{aligned}
$$

生産物価格は平均的には一定でありつつあ, 短期的 な上昇・下降運動をするという現状認識にたち，（A 3）を仮定した $\sigma_{p}$. が大きいほど価格の短期的な上昇 ・下降運動が激しいことを表わす。

（A 4) 農業経営における資本收益率の期待形成は, 次式で表現される.

$$
d r=\boldsymbol{\beta}(\bar{p} g-r) d t+\boldsymbol{\delta} r d p
$$

生産物価格の一時的な上昇・下降に対し, 農業経営 がしばしば近視腿的な期待形成をおこなうことも，よ く知られた事実である（例えば，頼・系原・横溝前掲 文献参照). 先に ( A 2 ) において経営計画之の整合性 のない投資を問題としたが，経営計画の前提之なる期 
待収益率の決定に関する確率的䚌乱を考慮すべく， （A 4)の仮定をおいた. 即ち, 農業経営は物的資本生. 産性に平均生産物価格を乗じたものへ之期待資本収益 率を調整する（(4)式右辺第 1 項）が，価格の上昇局面 では上方に，下降局面では下方に，期待形成がずれる 傾向がある（第 2 項）のである． $\delta$ が大きいほど，農 業経営の期待感が一時的な枝肉価格の上昇・下降海 感反応することを表わしている.

（A 5 ） 物的資本生産性は投資額の減少関数である.

$$
g=g(K) g^{\prime} \equiv \partial g / \partial K<0
$$

投資額が增大すれば，即ち規模拡大の速度が速まれ ば，経営管理能力の蓄積がおくれ，事故率の上昇など があたらされ，生産性が低下することを(A 5 )は表わ している．過急な規模拡大が経営破たんをあたらすて 之は, 頼・系原・横溝前揭文献はじめ, 多くの先行研 究において指摘されており，乙れをふまえて $(A 5)$ の 仮定をおいた ${ }^{10}$.

（A 6） 農業経営の外部資金の調達先は農協与信にか ぎられており, 与信量は農協の裁量下にある. 農協与信で不足する分は自己資本で補うが，そ れは具体的には家計資産のとりくずしという形 態をとる，農協与信利子率は一・定所与で自己資 本調達利子率（見つもり利子率）上りも低いむ のとする．自己資本調達利子率は家計資産残高 の減少関数之仮定する. 農協与信利子率が一定 所与であるから, 資本（総資本）調澾利子率は 家計資産残高の減少関数となる. 以上を数式表 現したあのが(6)，(7)式である.

$$
\begin{aligned}
& d W=(K-M) d t^{11)} \\
& i=i(W) \quad i^{\prime} \equiv \partial i / \partial W<0
\end{aligned}
$$

一般に農業経営における自己資本の蓄積にはきわめ て長期に要するてと, 農協の与信利子率が硬直的であ るととを考慮して，(A 6 ) の仮定をおいた ${ }^{12)}$.また， 自己資本調達利子率之嫁計資産残高の関俰について は, 農業経営の流動性制約に関する亀谷 ${ }^{13}$ の研究をふ まえたものである.

（A７）農協は, 次式にしたがって新規与信額を決定 する。

$$
\begin{aligned}
M & =f(K, W) \\
& =f_{\boldsymbol{\kappa}} K+f_{\boldsymbol{w}} W+M_{\boldsymbol{o}}
\end{aligned}
$$

（A 7 ）の仮定の意味は以下のとうりである, 農協は, 農業経営の投資額之家計資産残高を観察し，それに応 じて新規与信額を調整する. これが農協の与信制御で あり，てれを(8) 式のように 線型関数に単純化してい
る. 農協にとって, 農業経営の投資額, 家計資産残高 は関心の強い变数であると考え，てのような設定をと った（家計資産残高は担保を近以的に表現する变数と 考えることができる). $f_{\kappa}, f_{w}$ はそれぞれ，農業経営 の投資額を示す定数である. この定数をいかなる数值 に設定するかは農協の裁量下にあり, $f_{\kappa}, f_{w}$ の数值之農 業経営の安定性の関係を, (2)以降で理論的に解明する.

農業経営の投資いかんに無関係に新規与信額を農協 が決定するときには， $f_{\kappa}=0$ である. 現契の農協与信 を考えてみると，近代化資金など制度資金の適用によ り，農業経営の投資増大に対し新規与信の增大で対処 されている場合が多い. 即ち, 補助金政策から融資政 策へ之農政の重点が移行するなかで，農協の設定する $f_{\kappa}$ を増大させるべく政策的誘導がなされたのである. また，預託や購買末収金による金融方式も投資增大に と屯なう資金需要の增大を自動的に与信で補うあので あり，乙れら制度を農協が採用することは $f_{\kappa}$ を增大さ せるという意味を持つ. 第 3 節では, 上記の 3 制度の 導入・拡大によって $f_{\kappa}$ が増大することが農業経営にい かなる影響を与えるかを検討する，なお，上述のよう に $f_{\kappa}$ は正值である場合が多いと思われるが， $f_{\kappa}$ を負值 に農協が協定することあ可能である，それは，例え ば，農業経営の投資が増大するにつれ，制度金融，預 託，購買末収金と商用を抑制し，自己資本による投資 を促すという処置をとる場合である.

先述のとうり家計資産残高は担保を代理する变数で ある．有担保原則の証書融資に固執するかぎり， $f_{w}$ は 正值とならざるえない。しかしながら, 組合員勒定 は、農業経営の一時的な流動性不況を補うむのであ り，同制度の桩充によって $f_{w}$ を正值加ら負值へ，さら にはより絶対值の大きい負值仁設定できる. 第 3 節で は， $f_{\boldsymbol{w}}$ を小さくする $\left(\left(-f_{\boldsymbol{w}}\right)\right.$ を大きくする $)$ 性格を持 つという点に注目し, 組合員勘定と農業経営の安定性 との関係を考察する.ただ, 現状としては, 組合員勘定 が無制限に購買未収金のために使われがちであること は周知のとうりである. しかしながら本稿の 分析で は, 組合員勘定の制度としての特徵を强調する意図か ら, $f_{\boldsymbol{w}}$ との関連でもっぱら議論し, 組合員勘定と購買 未収金を区別してとりあつかう.

以上, 本稿のモデル分析は(1) ( 8 )式で構成され る. モデルの内生変数は $E, K, M, W, g, i, r$ であるが，そのうち独立な変数は $3 \supset ， K$ (現実の投 資額)， $r$ (期待資本收益率)，W (家計資産残高) 飞 まとめることができる，以上，(1)〜(8)式を，ての 
3 変数について整理する.

(1), (2), (7) 式より, $d K=\alpha(E(r, W)-K) d t+\sigma_{\kappa} K d Z_{\kappa}$ ただし $E_{\boldsymbol{w}} \equiv \partial E / \partial W=i^{\prime} E_{\boldsymbol{i}}>0$

(3) ( 5 ) 式上り, $d r=\beta(\bar{p} g(K)-r) d t+\delta r \sigma_{p} d Z_{p}$

(6),（8）式より, $d W=(f(K, W)-K) d t$

以上，(9) (11)式の連立方程式体系によって $(K$, $r, W)$ 動学経路が分析汀能となる. 均衡点のまわり での安定性を分析するために，(9)〜 (11)式を均衡点 のまわりで線型に閧開すれば，次のようになる.

$$
\begin{aligned}
& {\left[\begin{array}{l}
d K \\
d r \\
d W
\end{array}\right]=\left[\begin{array}{ccc}
-\alpha & \alpha E r & \alpha E_{w} \\
\beta \bar{p} g & -\beta & 0 \\
f_{k}-1 & 0 & f_{w}
\end{array}\right]\left[\begin{array}{l}
K-K^{*} \\
r-r^{*} \\
W-W^{*}
\end{array}\right] d t} \\
& +\left[\begin{array}{ccc}
\sigma_{k} & 0 & 0 \\
0 & 0 & 0 \\
0 & 0 & 0
\end{array}\right]\left[\begin{array}{l}
K \\
r \\
W
\end{array}\right] d Z_{k}+\left[\begin{array}{ccc}
0 & 0 & 0 \\
0 & \delta \sigma_{p} & 0 \\
0 & 0 & 0
\end{array}\right]\left[\begin{array}{l}
K \\
r \\
W
\end{array}\right] d Z p
\end{aligned}
$$

以下，(12)式にもとづいて, 農業経営の安定性分析 をおこなう。

\section{（2）内生変数の平均値ならびに分散についての安定 性分析}

吉川きの手法を準処として(12)式の体系について， 次の 2 点から安定性分析をおこなう. 第一は, 内生変 数の平均值についての安定性である. 内生変数 ( $K$, $r ， W ）$ の初期值が均衡点のまわりで任意に与えられ たとき，その平均値か洔間とともに均衡点へ収束する か発散するかの判別, ならびにその速度を検討するも のである.これは，結果的には，確定的体系（確摔的 鄮乱の存在しない体系）における安定性分析と一致す る.

第二は, 内生变数の分散についての安定性である. 確摔的贊乱の存在する体系汇おいては，たとえ平均值 についての安定条件が満たされていても, 内生変数 $(K, r, W)$ の分散が発散することがある. 内生変数 $(K, r, W)$ の分散が一定值に収束するか否かの判 別，ならびにその速度の検討が，分散についての安定 性分析である.（12)式の体系の安定性が高まるために は, 平均值についての安定性と分散についての安定性 の両者が，同時に高まらなければならない．

1）平均値についての安定性分析

（12）式より，ただちに平均値についての動学方程式 として, 次式を得る.

$$
\left[\begin{array}{l}
d \bar{K} \\
d \bar{r} \\
d \bar{W}
\end{array}\right]=\left[\begin{array}{lcc}
-\alpha & \alpha E r & \alpha E_{w} \\
\beta \bar{p} g & -\beta & 0 \\
f_{k}-1 & 0 & f_{w}
\end{array}\right]\left[\begin{array}{l}
\bar{K}-K^{*} \\
\bar{r}-r^{*} \\
\bar{W}-W^{*}
\end{array}\right] d t
$$

右辺の $3 \times 3$ 行列の固有值を $\lambda_{1}, \lambda_{2}, \lambda_{3}$ とすると, (13)式の微分方程式は次の上うに解かれる ${ }^{14}$.

$$
\begin{aligned}
& \bar{K}-K^{*}=a_{11} e^{\lambda_{1} t}+a_{12} e^{\lambda_{2} t}+a_{13} e^{\lambda_{3} t} \\
& \bar{r}-r^{*}=a_{21} e^{\lambda_{1} t}+a_{22} e^{\lambda_{2} t}+a_{23} e^{\lambda_{3} t} \\
& \bar{W}-W^{*}=a_{31} e^{\lambda_{1} t}+a_{32} e^{\lambda_{2} t}+a_{33} e^{\lambda_{3} t} \\
& \text { ここで } a_{u v}(u, v=1,2,3) \text { は定数 } \\
& H_{1}=\lambda_{1}+\lambda_{2}+\lambda_{3}=-\alpha-\beta+f_{w}<0 \\
& H_{2}=-\left(\lambda_{1} \lambda_{2}+\lambda_{2} \lambda_{3}+\lambda_{3} \lambda_{1}\right) \\
& =(\alpha+\beta) f_{w}+\alpha E_{w} f_{k}-\alpha \beta\left(1-\bar{p} g^{\prime} E_{r}\right)-\alpha E_{w}<0
\end{aligned}
$$

$$
\begin{aligned}
H_{3}= & \left.\left.\lambda_{1} \lambda_{2} \lambda_{3}=\alpha \beta\right\}\left(1-\bar{p} g^{\prime} E_{r}\right) f_{w}+E_{w} f_{k}-E_{w}\right\}<0 \\
H_{4}= & \left(\lambda_{1}+\lambda_{2}\right)\left(\lambda_{2}+\lambda_{3}\right)\left(\lambda_{3}+\lambda_{1}\right) \\
= & -(\alpha+\beta) f_{w}{ }^{2}-\left\{(\alpha+\beta)^{2}+\alpha E_{w}\right\} f_{w}-\alpha E_{w} f_{k} f_{w} \\
& \left.\left.-\alpha^{2} E_{w} f_{k}+\alpha\right\}(\alpha+\beta)\left(1-\bar{p} g^{\prime} E_{r}\right)+\alpha E_{w}\right\}<0 \quad(20)
\end{aligned}
$$

また, $\left(-H_{1}\right) \sim\left(-H_{4}\right)$ が大きいほど(13)式の体系の安 定性は高まる。

(17)～(20)式をみると, $\left(1-\bar{p} g^{\prime} E_{r}\right)$ の符号ならび に絶対值が重要な役割をはたすととがわかる．期待投 資額が期待資本収益率の增加関数 $\left(E_{r}>0\right)$ であれば, $\left(1-\bar{p} g^{\prime} E_{r}\right)>0$ であるが, 減少関数の之きは $\left(1-\bar{p} g^{\prime}\right.$ $\left.E_{r}\right)$ の符号は負となることあある. ここで，

$1-\bar{p} g^{\prime} E r<0 \leftrightarrow\{\partial(\bar{p} g) / \partial K\}(\partial E / \partial r)>1$ であること に注意すれば, $\left(1-\bar{p} g^{\prime} E_{r}\right)<0$ は, 農業経営窮迫生産 の状態に陥り, 収益率の低下之過大投資の悪循環が発 生しやすい状態にあることを示すことがわかる，以下 では, $\left(1-\bar{p} g^{\prime} E_{r}\right)>0$ となる農業経営を「成長型農業 経営」, $\left(1-\bar{p} g^{\prime} E_{r}\right)<0$ となる農業経営を「窮迫生産型 農業経営」と表現するとととする.

（17）（20)式の解を図示すれば, 図 A（成長型農業 経営), 四 B(窮迫生産型農業経営)，のようになる. 斜 線部が解領域で，(17)〜 (20)式の安定条件が満たされ る領域を示している.ささらに, 矢印の方向に行くにし たがって安定性が高まる.「成長型農業経営」と「窮迫 生産型農業経営」で異なる点は $f_{\kappa}$ を一定値に固定した 場合，前者では $\left(-f_{\boldsymbol{w}}\right)$ を大きくするほど安定性は高ま 
平均値についての安定性の図示

図A

成長型農業経営について

$\left(\left(1-\overline{\mathbf{p}} \mathbf{g}^{\prime} \mathrm{Er}\right)>0\right)$

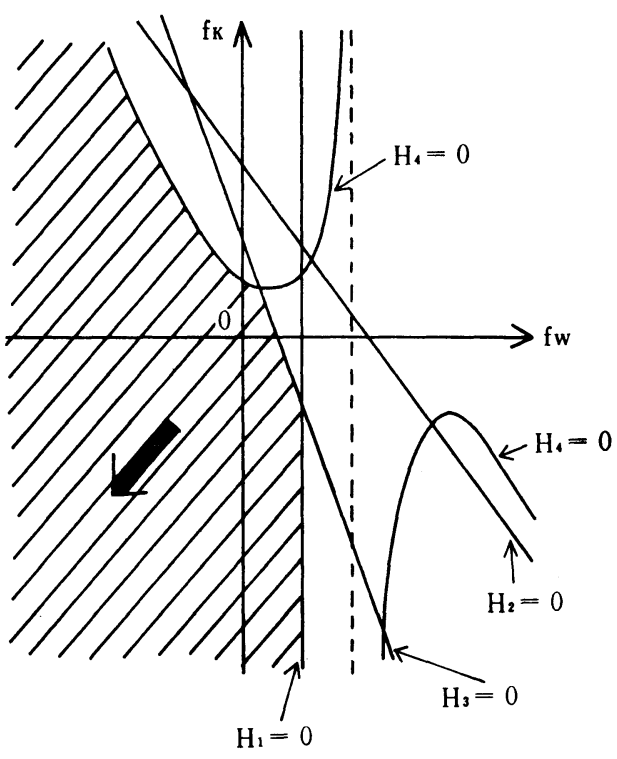

るのに対し, 後者ではある限度をこえると $\left(-f_{w}\right)$ の増 大が逆に安定性を低めるように作用することである.

また，詳細な証明は省略するが，いずれの農業経党で も，(-f $\left.f_{\kappa}\right)$ が大きいほど安定性が高まる.

図 $\mathrm{A} ， \mathrm{~B}$ で示される数学解に対して，節をあらた め，3の(2)で経済的考察をおてなう。

2）分散についての安定性

$K$ (投資額)， $r$ (期待資本収益率)， $W$ (家計資産 残高）について, 分散が一定值に収束するか否かの判 別，ならびにその速度の検討をおてなう．そこで，

$$
Y=E(K-\bar{K})^{2}+E(r-\bar{r})^{2}+E(W-\bar{W})^{2}
$$

ただし $E$ は期待值を示す

を考え，これが時間ととあにどのような経路をたどる かを調べる17.

(12)式と伊藤の微分則より次式を得る18)。

$$
\begin{aligned}
& \frac{d Y}{d t}=E\left\{[ \begin{array} { l } 
{ K - \overline { K } } \\
{ r - \overline { r } } \\
{ W - \overline { W } }
\end{array} ] ^ { T } \left[\begin{array}{lc}
-2 \alpha+\frac{1}{2} \sigma_{k}^{2} & 2 \alpha E r \\
2 \beta \bar{p} g & -2 \beta+\frac{1}{2}\left(\delta \sigma_{p}\right)^{2} \\
2\left(f_{k}-1\right) & 0
\end{array}\right.\right. \\
& \left.\left.\begin{array}{c}
2 \alpha E_{w} \\
0 \\
2 f_{w}
\end{array}\right]\left[\begin{array}{l}
K-\bar{K} \\
r-\bar{r} \\
W-\bar{W}
\end{array}\right]\right\}+\left(\sigma_{\kappa} \bar{K}\right)^{2}+\left(\delta \sigma_{p} \bar{r}\right)^{2} \\
& \text { ただし，Tは転置を表わす。 }
\end{aligned}
$$

図B

穿迫生産型農業経営について

$\left(\left(1-\overline{\mathrm{p}} \mathbf{g}^{\prime} \mathrm{Er}\right)<0\right)$

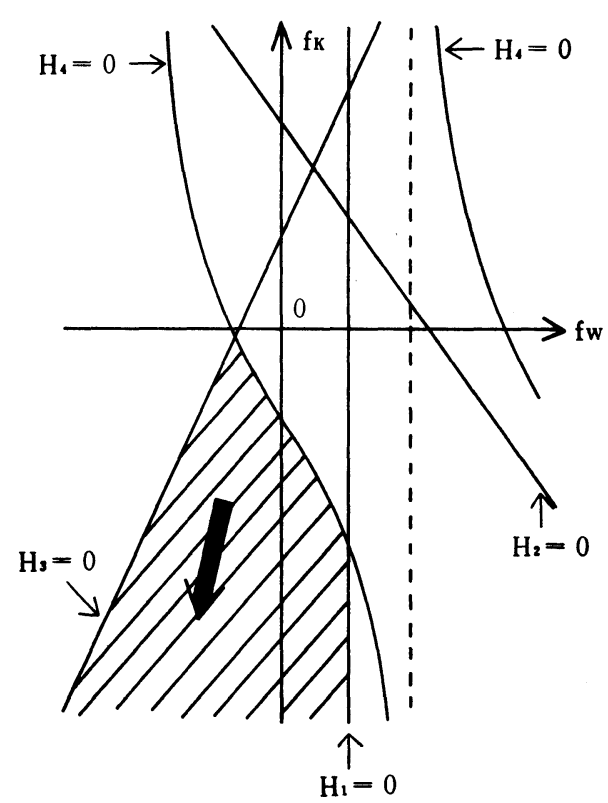

ただし， $T$ は転置を表わす。

平均値についての安定性が成立し，かつ，右辺第 1 項 の $3 \times 3$ 行列の固有值 $\lambda_{1}^{\prime}, \lambda_{2}^{\prime}, \lambda_{3}^{\prime}$ の実数部分が負之 なる $\left(\lambda_{1}^{\prime}, \lambda_{2}^{\prime}, \lambda_{3}^{\prime}\right.$ についてルース，ハービッッ条件が 成立する)ととが，(22)式の体系の安定条件である ${ }^{19}$. $\lambda_{1}^{\prime}, \lambda_{2}^{\prime}, \lambda_{3}^{\prime}$ についてのルース・ハービッッ条件は，(13） 式で $(-\alpha)$ が $\left(-\alpha+\frac{1}{4} \sigma_{k}^{2}\right) に,(-\beta)$ が $\left.-\beta+\frac{1}{4}\left(\delta \sigma_{p}\right)^{2}\right\}$ に置きかわったあの之同一であり，先に(17)〜 (20) 式を導出したあのと同手順で導出できる（紙幅の制約 上，その展開は省略する). これにより以下のことを 確認することができる、第一に確率的筧乱が存在し なりれば $\left(\sigma_{\kappa}=\delta \sigma_{p}=0\right.$ であれば), 分散についての安 定性は(13)式加導加る平均值についての安定性と 一致する. 第二に，確率的摫乱が大きければ，分散に ついての安定条件は平均値についての安定条件之非離 する. その結果, 平均值についての安定性を高めるへ く $\left(f_{\kappa}, f_{w}\right)$ を設定するてとが, 分散についての安定性 と矛盾しかねない，また， $\sigma_{k}^{2},\left(\delta \sigma_{p}\right)^{2}$ が著しく大きく ない範囲内で, かつ, 平均値についての安定条件が成 立しているのであれば, 確率的䚓乱の増大は分散につ いての安定性を低める効果を持つ.

さらに，仮定より自明のことであるが，確率的搳乱 
の增大は(22)式右辺第 2 項, 第 3 項を大きくする. こ のととは均衡状態に打ける分散（分散が漸近的に収束 する值）が大きくなるととを意味している．乙のよう に，確率的靦乱の増大は分散についての安定性を阻害 る点と均衡状態における分散を大きくする点の 2 点に おいて，農業経営の成長・発展に望ましくない影響を 与えるのである.

以上のように求められた数学解に対して, 次節 3 の (1)で経済的考察を加える.

\section{3. 農業経営の安定性強化と与信制御}

前節では, 数学的に農協の与信制御と農業経営の安 定性との関係を示した，本節では，乙れにあとづき， 経済学的考察をおこなう。

（I）農協の与信制御が有効となるための条件

まず，分散についての安定性分析の結果から，農協 の与信制御が有効となるための条件を考えることがで きる.

確率的筧乱（計画性の乏しい投資誘因や生産物価格 の短期的変動による資本収益率の期待形成上の贊乱な ぞ)が小さければ平均值についての安定性を高めるて とによって分散についての安定性をも高めることが可 能であり, 農協の与信制御による農業経営の安定性強 化はおこないやすい，一方，確率的攪乱が大きければ 平均値についての安定性之分散についての安定性が矛 盾し, 農協の与信制御による農業経営の安定性強化は 困難なるのとなる，さらに，確率的攪乱の増大は均衡 状態における分散を大きくするはたらきをもつ。

したがって，農業経営における確率的攬乱が小さい ことが，農協の与信制御を有効なものとするために必 要とされる条件であるといえる。

このととに関連して，以下のような推論が可能であ ろう．確率的撜乱の発生を抑制するためには，農業経 営は経営管理能力を蓄積し, 長期的な展望にもとづく 計画的な投資行動が抽てなわれなければならない，そ のためには, 農協の営農指導の総合化・高度化が非常 亿重要之なるのではないかと思われる. 実䟢, 多くの 論者が，単に農協与信のあり方をただすだけではな く，営農指導のあり方をむ改善すべきことを主張して いる201，逆にいえば，金融制度の手直しを䏠てなうだ けでは, 農業経営の安定性を強化することは困難であ ると思われる。

（2）いかなる与信制御が農業経営の安定性を強化す るか
つぎに，農業経営における確率的筧乱が小さく，平 均値についての安定性を高元ことによって農業経営 の安定性を高めることができる歾合について，農協の 与信制御之農業経営の安定性について議論する. 前節 でおてなった平均值についての安定性分析の結果（戍 A，B）にあとづき，経済学的考察をおこなう.

1）農業経営の投資額に対する与信制御䛃

「成長型農業経営」「筙迫生産型農業経営」のいず れの場合であれ， $f_{\kappa}$ （農業経営の投資額侄対する限界 新規与信額）を負值にすることにより，さらに $\left(-f_{\boldsymbol{\kappa}}\right)$ を大きくすればするほよ゙，農業経営の安定性が高まる ことが示された．このととは，農業経営の投資増大時 には農協は新規与信を抑制し，農業経営の自己資本に よる投資を促すべきことを意味している．既存の事例 研究の多くが，農協与信倍存した投資行動が経営破 たんの一因となる場合が多いことを指摘しているが， 本稿の分析結果はそれらの指摘之整合的である ${ }^{211}$.

一方, 先述のとうり, 農協が制度資金, 預託, 購買 未収金の導入・拡大をおこなうとき，(-f る. 農業経営の安定性という観点にたつかぎり，乙れ ら制度はきわめて問題のある制度であり，その適用は 慎重でなければならない，政府の制度金融が農業経営 の安定性を低める性格を持つてとが明らかになったて とは重要であろう，自立経営の育成を目的として，近 代化資金制度，さらには総合施設資金制度というよう に，規模桩大に対する包括的な与信が政策的におてな われてきたが，上述のような観点から，批判的に制度 金融のあり方を再検討するべきであろう.

2）農業経営の家計資産残高に対する与信制御につ いて

$f_{w}$ （家計資産残高に対する限界新規与信額）のとる べき值は，「成長型農業経営」の場合と「窮迫生産型 農業経営」の場合とで異なる．前者の場合は $f_{w}$ は負值 で，かつ $\left(-f_{w}\right)$ が大きいほど農業経営の安定性は高ま る. しかし後者の場合は $f_{\kappa}$ の值に応じて農業経営の安 対性を最も高める $f_{\boldsymbol{w}}$ の值が決まり，それを上回ってむ 下回っても安定性は低下する．とくに $\left(-f_{\kappa}\right)$ が小さい ほど, 安定条件を満たす $f_{w}$ の值の領域は小範囲に限定 される.

先述のとうり，組合員勘定は $\left(-f_{w}\right)$ を大きくする性 格を持つ. 農協が有担保での与信に固執するかぎり, $\left(-f_{w}\right)$ は小さくならざるをえない。成長型農業経営」 の場合は, 組合員勘定を積極的に適用し, $\left(-f_{\boldsymbol{w}}\right)$ を大 きくすることによって農業経営の安定性を高めること 
ができる.乙の場合「有担保原則の厳守, イコール， 農協与信の改善」とはならないととに注意すべきであ る.しばしば組合員勘定が諸悪の根源であるかのよう に批判されるのであるが，それは組合員勘定が現実的 には購買未収金のために無制限に利用されているとと が問題なのであって（つまり，利用のされ方が問題な のであって)制度自体は有用なあのであると思われる. ただし、「筙迫生産型農業経営，の場合は，とりわ け $\left(-f_{\kappa}\right)$ が大きくない場合は， $f_{w}$ はゼロに近く設定せ ざるをえない. $\left(-f_{w}\right)$ の設定が大きくなりすぎると， 農業経営の安定性は低まってしまうからである. ての ように「筙迫生産型農業経営」の場合は, 組合員勘定 の制度としての有用性を主張することは難しくなる.

「窮迫生産型農業経営」の場合は, $\left(-f_{\kappa}\right)$ を大きくす ることこそが必要とされるのである.

\section{4. まとめと今後の課題}

本稿では, 先行研究をふまえ, 農業経営の安定性と 農協の与信制御の関係を論じてきた. 平均値の変動と 確率的筧乱との区別, 「成長型農業経営」と「窮迫生 産制農業経営」の区別など，新しい視点を持つととに より, 農協与信のあり方をより明確に判断できること が示されたと思う．乙れらの概念上の区別は，従来の 研究においては必ずしも明確とはなっていなかったて とである.

しかし, 本稿の分析枠組みは, いくつかの改善すべ き点が残されている. 第一に, 農協の行動原理につい ての考察が不足している．例えば，与信制御には費用 （非金銭的な費用むふくめて）がかかるはずであり， この点に関して検討をすすめたい. 第二に, 農業経営 における短期資金と長期資金の差異を明確にしなけれ ばならない，資本利用型農業経営において，投入・産 出の時差, 生産要素としての資本財の固定性は重要問 題であると思われ，短期資金と長期資金ではその役割 におのずと差異があるはずである.

以上のようなモデルの改良をおてなえば,より戦密, かつ正確な分析が可能となろう.ささらに, 単なる理論 面の精維化にとどまらず，実証面からの発展をところ みることが，筆者に残された大きな課題である.

注 1) 本稿の分析をすすめるうえで参考とした既存研 究のうちおもだうたものを以下にあげる。『長期 金融一特集・肉牛の生産構造と経営問題』63号, 農林水産長期金融協会, 1984. 『農業之経済一特
集・農家負債の現代的性格と対策』6 月号, 富民 協会, 1983. 『譬業と経済一特集・農家負債と農 協』12月号, 富民協会, 1986. 頼平・系原義人・ 横溝功『大規模畜産経営における負債の重圧の実 態之今後の課題に関する調查研究書』農業開発セ ンター, 1984. 亀谷是「農家負倩について」, 『農 林金融』第38巻第 12 号，1985. 日暮賢司「固定化 負債の発生メカニズムとその構造に関する分析」, 『農村研究』1985. 平川輝夫「低豚価時代に入っ た農業経営の問題点」『畜産コンサルタント』第 259号, 1986. 宮崎宏「肉用牛経営の問題点と関 連政策」, 農業経営研究』第 23 卷第 2 号, 1983.

2) 安定性分析の経済学的意義つけを詳しく記述し たものとして, 次の文献を参照されたい.なお， 本稿における用語法は同文献にならっている. 吉 田和男『日本経済の活力と企業行動』東洋経済新 報社, 1985 .

3）この点に関しては次の文献参照. 系原義人「農 家負債に対する農協の対応」、『農業と経済』12月 号, 1986.

4) 吉田前掲文献.

5 ) 吉川洋『マクロ経済学研究』東京大学出版会, 1984. H. Yoshikawa, “Alternative Monetary Policies and Stability in a Stochastic Keynsian Model" International Economic Review, October 1981.

6） S. J.ターノフスキー著, 石弘光・油井雄二訳 『マクロ経済分析と安定政策』マグロウヒル好学 社, 1980.

7 ）木村英紀『動的システムの理論』産経困書, 1974. 本稿のモデルの基本的発想は, 外生変数 (経営環境)に反応して行動する一種の動的シス テムとして農業経営をみなし，農協与信はそれに 対するレギュレータとして扱っている. 動的シス テムの数学理論は, むとあと制御工学の分野で応 用されていたが, 近年は経済学の分野であ数多く 導入されている:

8 ）仔豚価格一定と仮定しているので, 投資額は投 入する豚の数と比例する.

9) Wiener 過程に関しては, 詳しくは以下の文献 を参照されたい，P．サミュエルソン著，佐藤隆 三訳『経済分析の基礎(増補版)』頸草書房, 1986, 数学付論 C. K. J.アストローム著, 中村嘉平ほ 加訳『確率制御理論入門』コロナ社, 1975.

10）（5）式は資本の限界生産性聥減を意味している のではない，Kは投資額（規模拡大の速度）を示 しており，資本ストックとは異なる。（5)式は, あくまであ規模拡大の過急性による生産性の悪化 
を問題としているのである.

11) 農業資産 $(J M d t)+$ 家計資産 $(W)=$ 自己資本(仮 定より一定) +農協与倍 $\left(\int K d t\right)$

という，貸借対照表上の怕等式から得られる.

12）ただし，自己資本の蓄積や，借入額の増大に対 する農協与信利子率の聥増を仮定してモデルを複 雑化した場合であ，本稿の分析結果は基本的に維 持される。

13）亀谷是「農業における資金・盱務管理の基礎理 論」, 農業計算学研究』第 17 号, 1984.

14）岡村哲治・蔵田久作・小山昭雄『経済数学』佰 斐閣， 1975 ，第11章。

15）ルース・ハービッッ (Routh-Hurwitz) 条件に ついては, サミュエルソン前掲書数学付論 B参照.

16）きわめて偶然のケースとして, $1-\bar{p} g^{\prime} E_{r}=0$ と なる場合がある。とのときの安定性分析をおこな えば，「成長型農業経営」の場合に類似した結果 が導かれる。

17） $K ， r ， W$それれの分散について異ったウェ イトつけをして，以下に定める $Y^{\prime}$ を想定する場 合も，本稿と全く同じ結論が得られる。

$$
\begin{aligned}
Y= & b_{1} E(K-\bar{K})^{2}+b_{2} E(r-\bar{r})^{2} \\
& +b_{3} E(W-\bar{W})^{2}
\end{aligned}
$$

（ただし， $b_{1} ， b_{2} ， b_{3}$ は非負の定数）

たとえば， $b_{1}=1, b_{2}=b_{3}=0$ とすれば $K$ について のみの分散となる（ $r ， W$ についても同様），乙 のように(21)式の分散の検討によって， $K, r$, $W$ 分散の検討屯同時におこなわれるのである.

18）Wiener 過程の関数となっている確率過程を微 分するときに用いられるのが伊藤の微分則であ る. 伊藤の微分則については次の文献が要領よく まとめている（詳細な説明については，アストロ ーム前掲書を参照). 久保田敬一『ポートフォリ 才理論』日本経济壾論社，1981，第 5 章。

19）(14) (16)式の $\lambda_{1} 、 \lambda_{2} 、 \lambda_{3}$ ならびに $\lambda_{1}^{2} 、 \lambda_{2} ， \lambda_{3}^{\prime}$ を用い

$$
\begin{aligned}
& \text { ると，(22)式の…般解は次のように書ける. } \\
& Y=c_{1} e^{\lambda_{i} t}+c_{2} e^{\lambda_{2} t}+c_{3} e^{\lambda_{3} t}+c_{1} e^{i \lambda_{i}+\lambda_{i} t} \\
& +c_{5} e^{\left(\lambda_{2}+\lambda_{3}\right) t}+c_{6} e^{\left(\lambda_{3}+\lambda_{i} t\right.}+c_{7} e^{\lambda_{1} t} \\
& +c_{8} e^{\lambda_{2} t}+c_{9} e^{\lambda_{3} t}+c_{10} e^{\lambda_{1}+\lambda_{2} / t} \\
& +c_{11} e^{\lambda_{2}+\lambda_{3} i t}+c_{12} e^{\lambda_{3}+\lambda_{1} t} \\
& \text { (ただし， } c_{1} \sim c_{12} \text { は初期值に忍じて決定さ } \\
& \text { れる定数) }
\end{aligned}
$$

20）例えば，日暮前掲文献参照.

21）例えは，頼・系原・横溝前掲文献参照。

（筆者・滋賀県立短期大学農業部） 